\title{
Eksistensi sedekah bumi di era modern: Desa wisata Plesungan Kecamatan Gondangrejo Kabupaten Karanganyar
}

\author{
Nabila Masruroha, ${ }^{\mathrm{a}, 1}$, Abdul Rahman ${ }^{\mathrm{b}, 2^{*}}$, Yosafat Hermawan ${ }^{\mathrm{c}, 3}$ \\ abc Universitas Sebelas Maret, Jalan Ir. Sutami no. 36, Surakarta, 57126, Indonesia \\ ${ }^{1}$ nabila230899@gmail.com; ${ }^{2}$ abdul.rahman@staff.uns.ac.id; ${ }^{3}$ yosafathermawan@staff.uns.ac.id
} * Corresponding Author

\begin{tabular}{l}
\hline INFO ARTIKEL \\
\hline Sejarah Artikel: \\
Diterima: 4 Juli 2021 \\
Direvisi: 31 Agustus 2021 \\
Disetujui: 21 September 2021 \\
Tersedia Daring: 31 Oktober \\
2021 \\
\hline
\end{tabular}

Kata Kunci:

Desa Wisata Plesungan

Eksistensi

Perubahan

Resik Deso

Sedekah Bumi

\begin{abstract}
ABSTRAK
Masyarakat Jawa tidak lepas dengan budaya juga tradisi yang menjadi ciri khas daerahnya. Salah satunya tradisi sedekah bumi di Jawa menjadi manifestasi bentuk rasa syukur. Warga Plesungan masih menjaga tradisi ini meskipun mayoritas bukan petani dan tergolong masyarakat urban. Tujuan penelitian ini melihat sejarah tradisi sedekah bumi di era modern, makna yang terkandung pada tradisi sedekah bumi, proses tradisi dan dinamika untuk menyimpulkan eksistentesinya. Metode penelitian yang digunakan adalah deskriptif kualitatif untuk menggambarkan fakta tentang tradisi sedekah bumi. Sumber data penelitian adalah informan dan fenomena tradisi sedekah bumi. Teknik pengumpulan data dengan observasi, wawancara, dan dokumentasi. Teknik analisis data dengan menggunakan tiga tahap yaitu reduksi data, penyajian data, dan penarikan kesimpulan. Penelitian ini menyimpulkan bahwa tradisi sedekah bumi telah dilaksanakan turun-temurun sejak nenek moyang, masyarakat melihat tradisi ini wajib dilaksanakan dan dilestarikan karena banyak menanamkan nilai-nilai luhur yang baik seperti gotong royong juga silaturahmi dengan adanya perubahan tersebut masyarakat Desa Plesungan mengambil sisi baik sebagai pengenalan tradisi sedekah bumi kepada generasi penerus agar tidak
\end{abstract} hilang ditelan zaman.

\section{ABSTRACT}

Keywords:

Plesungan Tourism Village

Existence

Change

Resik Deso

Sedekah Bumi
Javanese society cannot be separated from the culture and traditions that characterize the region. One of them is the earth alms tradition in Java which is a manifestation of gratitude. The people of Plesungan still maintain this tradition even though the majority are not farmers and belong to the urban community. The purpose of this study is to look at the history of the earth alms tradition in the modern era, the meaning contained in the earth alms tradition, the traditional process and the dynamics to conclude its existence. The research method used is descriptive qualitative to describe facts about the earth alms tradition. Sources of research data are informants and the phenomenon of the earth alms tradition. Data collection techniques by observation, interviews, and documentation. The data analysis technique uses three stages, namely data reduction, data presentation, and drawing conclusions. This study concludes that the earth alms tradition has been carried out from generation to generation since the ancestors, the community sees this tradition as obligatory to be implemented and preserved because it instills many good noble values such as mutual cooperation and friendship. the tradition of giving the earth alms to the next generation so that it is not lost in time. 
How to Cite: Masruroh, N., Rahman, A., \& Hermawan, Y. (2021). Eksistensi sedekah bumi di era modern: Desa wisata Plesungan Kecamatan Gondangrejo Kabupaten Karangnyar. Satwika : Kajian Ilmu Budaya dan Perubahan Sosial, 5(2), 268-283. https://doi.org/10.22219/satwika.v5i2.17209

\section{Pendahuluan}

Kebudayaan lahir karena keinginan manusia untuk memenuhi kebutuhan hidupnya, dalam bentuk tingkah laku, perekonomian, religi, mitos dan sebagainya. Kebudayaan merupakan suatu peralatan simbolik bagi pengontrol perilaku sehingga proses kebudayaan harus dipahami, diterjemahkan, dan diinterpretasi (Riezal et al., 2019). Budaya juga merupakan keseluruhan kompleks yang meliputi pengetahuan, kepercayaan, kesenian, moral, keilmuan, hukum, adat istiadat, dan kemampuan yang lain serta kebiasaan yang didapat oleh manusia sebagai anggota masyarakat (Astuti, 2019).

Sebagai suatu sistem budaya, tradisi menyediakan seperangkat model untuk bertingkah laku yang bersumber dari nilainilai setempat atau sistem nilai dan sistem gagasan. Sebagaimana diketahui, tradisi dan kebudayaan dapat dipengaruhi oleh letak geografis, keadaan, struktur dan iklim suatu wilayah yang keberadaannya memberikan pengaruh yang besar terhadap kehidupan masyarakatnya (Nurrofika \& Murdiono, 2020). Tradisi sebagai kebiasaan yang harus dijaga meski telah mengalami tantangan, baik tantangan sosial ekonomi maupun budaya (Supriatna \& Nugraha, 2020). Tradisi dan tindakan orang Jawa selalu berpegang pada dua hal. Pertama, pada filosofi kehidupan religius dan mistis. Kedua, etika hidup yang menjunjung tinggi akhlak dan derajat kehidupan (Prasasti, 2020).

Dalam suatu tradisi terdapat ritual atau prosesi acara yang berlangsung. Ritual merupakan transformasi simbolik dan ungkapan perasaan dari pengalaman manusia dan hasil akhir dari artikulasi yang sedemikian itu merupakan emosi yang spontan dan kompleks (Alkaf, 2013). Salah satu ciri budaya Jawa yang menonjol adalah budaya upacara selamatan atau syukuran. Selamatan adalah upacara makan bersama, yang dalam bahasa Jawa sehari-hari disebut slametan (Prasasti, 2020). Upacara selamatan dapat diartikan dengan upacara pengorbanan, masyarakat adat akan mengorbankan material, tenaga dan juga waktu untuk melaksanakan upacara slametan ini. Upacara pengorbanan dilakukan oleh para petani dan nelayan masyarakat yang telah menganut nilai-nilai Islam, baik dalam bentuk sedekah bumi dan tolak sial (Pakuna et al., 2020).

Salah satu tradisi yang dianggap jenis selamatan adalah sedekah bumi karena bertujuan sebagai ucapan rasa syukur atas anugerah dan karunia yang diberikan Tuhan Yang Maha Esa atas keberhasilan panen. Salah satu tradisi selamatan yang masih langgeng adalah sedekah bumi di Desa Plesungan, Gondangrejo, Karanganyar.

Secara umum, tradisi sedekah bumi menyediakan persembahan makanan yang berlimpah bukan hanya sebuah kebutuhan tetapi pada saat yang sama juga menjadi daya tarik bagi warga untuk menghadiri acara tersebut (Pakuna et al., 2020). Upacara sedekah bumi juga merupakan salah satu tradisi yang menjadi bukti nyata bahwa negara Indonesia memiliki budaya yang sangat beragam dibandingkan dengan tradisi budaya lainnya (Arinda, 2016). Terlebih pada masyarakat pertanian, masyarakat pertanian yang masih mempraktikkan budaya pertanian adalah masyarakat yang mengerti dengan baik apa yang telah diyakini dan dilaksanakan oleh para nenek moyang mereka dari generasi ke generasi dan menghormati budaya yang mereka 
yakini kesucian dan keluhurannya (Supriatna \& Nugraha, 2020).

Dalam kehidupan era modern ini, manusia mengalami perubahan atau dalam proses transformasi yang begitu cepat. Generasi berikutnya tidak akan mengenali budaya mereka karena telah dihapuskan oleh periode modernisasi. Bahkan jika berlanjut akan berdampak buruk pada budaya lokal yang ada dan salah satunya tradisi. Hambatan harus dilawan melalui ketahanan budaya, sosial, dan ekonomi (Mangunjaya et al., 2020).

Tradisi dan modernitas masing-masing tidak bisa disatukan karena keduanya berbeda orientasi (Jalil, 2019). Dengan orientasi yang berbeda tersebut kita dapat mencermati bahwa modernisasi terjadi dengan segala kecanggihan sarana dan media modern yang akan memberi kesempatan bagi cakrawala baru dalam tatanan kehidupan dimasa mendatang. Dengan berkembangnya teknologi informasi pada kehidupan masyarakat menjadi salah satu faktor besar yang mendorong terjadinya perubahan budaya dalam kehidupan sosial. Perubahan sosial budaya adalah gejala berubahnya struktur sosial dan pola budaya dalam suatu masyarakat (Guntoro, 2020).

Kenyataan lain menunjukkan bahwa negara berkembang, termasuk Indonesia, lebih banyak dipengaruhi oleh negaranegara maju (Hastuti et al., 2021). Modernisasi dengan icon utamanya, yakni teknologi informasi dan komunikasi mendatangkan pengaruh besar dalam kebudayaan masyarakat Indonesia (Cholifah, 2013).

Perubahan pada sosial budaya, pengaruh dari budaya lain, penyesuaian nilai norma, pengaruh media modern inilah yang dapat merujuk pada perubahan tradisi. Jadi, perubahan sosial budaya dipengaruhi oleh fenomena modernitas yang menyebabkan perubahan tatanan sosial budaya salah satunya tradisi.

Masuknya budaya asing memperkaya warna kebudayaan Indonesia. Budaya asing masuk melalui tiga macam cara yaitu difusi, akulturasi, dan asimilasi (Roszi \& Mutia,
2018). Pada proses akulturasi kita dapat melihat perubahan yang patut terjadi pada suatu budaya. Sebagai suatu proses sosial yang timbul jika suatu kelompok manusia dengan suatu kebudayaan tertentu dihadapkan dengan unsur-unsur dari suatu kebudayaan asing dengan sedemikian rupa, sehingga unsur-unsur kebudayaan asing itu lambat laun diterima dan diolah ke dalam kebudayaan sendiri tanpa menyebabkan hilangnya kepribadian kebudayaan itu sendiri (Firmansyah, 2016). Akulturasi selalu ditandai dengan perubahan secara fisik dan psikologi yang terjadi sebagai hasil dari adaptasi yang dipersyaratkan untuk memfungsikan dalam konteks budaya yang baru atau budaya yang berbeda (Utami, 2015).

Dengan begitu, perlu adanya perisai untuk menjaga kelanggengan dari suatu tradisi. Hubungan sebab akibat yang bersifat dualistik ini merupakan konseptualisasi dialektik atas budaya; dialektika ini juga menjamin adanya diferensiasi budaya atas struktur sosial (Jenks, 1993). Sebagai pemuda harus menentukan langkah apa saja untuk menjaga eksistensi budaya lokal dengan menggunakan perkembangan teknologi yang ada (Fitri et al., 2018).

Perlunya sikap tegas sangat dianjurkan dalam melanggengkan suatu budaya yang tersentuh oleh arus modern. Sikap tegas untuk memilah hal baik dan buruk, selalu mendukung kelestarian budaya dengan ikut melaksanakan dan mengedukasi diri bahwa tradisi tersebut perlu dilestarikan adalah suatu kunci yang perlu ditanamkan oleh para generasi muda karena mirisnya rasa ingin tahu tentang budaya yang mereka miliki seperti salah satu pepatah mengatakan "wong Jowo ojo lali jawane" (orang Jawa jangan lupa jawanya).

Beberapa penelitian yang relevan dengan penelitian ini sebagai berikut, penelitian pertama tentang pelestarian sedekah bumi yang dilihat sebagai budaya lokal. Dalam penelitian di Dusun Wonosari Desa Tebang Kacang membahas tentang terpeliharanya tradisi Sedekah bumi yang merupakan kebudayaan milik suku Jawa 
(Prasasti, 2020). Ada tiga pokok sistem yaitu sistem upacara daur hidup dan sistem upacara daur waktu, adat pergaulan dan kesenian. Agenda Sedekah Bumi yang dilakukan Dusun Wonosari Desa Tebang Kacang ada tiga di antaranya penyembelihan sapi yang dilakukan setelah waktu subuh, disusul kenduri untuk penyajian sesajen dan pengolahan sapi. Malam harinya menampilkan pagelaran wayang sebagai contoh untuk masyarakat. Wayang ini adalah pedoman bagi orang Jawa, maka penokohan ketika sedekah bumi juga lakon baik-baik yang sering di pertontonkan adalah "Babat Alas Mertani" yang mempunyai arti membuka sebuah hutan (Lestari, Evi Dwi, 2018). Jadi pada penelitian ini terlihat bahwa ritual pelaksanaan sedekah bumi berbeda dengan yang penulis teliti.

Penelitian selanjutnya berfokus pada paradigma agama Islam. Nugroho (2018) melihat ada beberapa unsur yang dapat dipandang sebagai kebaikan, seperti terciptanya suasana kebersamaan dan persaudaraan, terciptanya suasana gotong royong dan kerjasama, serta membangun jiwa pengorbanan. Nilai-nilai ini pada prinsipnya tidak bertentangan dengan nilai Islam. Namun di sisi lain, upacara sedekah bumi mengandung juga unsur-unsur yang bertentangan dengan ajaran Islam, bahkan termasuk perbuatan syirik. Adanya keyakinan masyarakat bahwa sedekah bumi dengan bermacam perayaanya seperti ombyok sapi akan mendatangkan keselamatan, kesuburan dan keberhasilan hasil bumi adalah keyakinan yang tidak diperbolehkan dalam Islam. Selain itu, tradisi memasukan makanan, padi, singkong dan berbagai hasil bumi ke lubang yang telah disediakan sebelumnya oleh mereka dianggap sebagai wujud syukur ke bumi. Dalam perspektif Islam, hal demikian jelas bertentangan karena termasuk perbuatan mubazir (Nugroho, 2018). Pada penelitian ini melihat adanya unsur yang bertentangan dengan ajaran agama Islam yaitu ritual ombyok sapi dan pada penelitian yang dilakukan penulis tidak terdapat ritual yang dianggap bertentangan dengan ajaran agama.

Penelitian ketiga, penelitian ini membahas tradisi Sedekah Bumi yang berfokus nilai-nilai pendidikan pada masyarakat Desa Bagung Sumberhadi (Fitri et al., 2018). Nilai-nilai pendidikan yang terkandung dalam upacara sedekah bumi di Desa Bagung Sumberhadi terdiri atas tiga nilai, yaitu: (a) nilai pendidikan ketuhanan, (b) nilai pendidikan sosial atau kemasyarakatan, (c) nilai pendidikan moral. Nilai pendidikan ketuhanan dalam upacara Sedekah Bumi membuat masyarakat Desa Bagung Sumberhadi lebih percaya adanya Tuhan. Masyarakat lebih tekun beribadah, lebih mensyukuri nikmat dan rizki yang diberikan Tuhan. Nilai pendidikan sosial atau kemasyarakatan, membuat masyarakat Desa Bagung Sumberhadi dapat saling berkomunikasi dengan baik, saling tolong menolong dan membantu. Nilai pendidikan moral dalam upacara sedekah bumi membuat masyarakat Desa Bagung Sumberhadi memiliki etika baik, tingkah laku warga menjadi baik, dan saling menjaga sikap.

Dari beberapa hasil penelitian yang terdahulu terkait dengan tradisi sedekah bumi, maka peneliti mencari hal yang lain dan lebih mengerucut. Dalam penelitian ini penulis mendeskripsikan eksistensi tradisi sedekah bumi di Desa Plesungan pada era modern ini. Desa ini termasuk desa wisata yang terdapat objek wisata Sendang Plesungan yang telah dibangun selama hampir dua tahun belakangan dan mayoritas masyarakat Plesungan adalah masyarakat urban. Kebaharuan yang didapatkan oleh penulis sebab terjadi beberapa perubahan budaya pada tradisi sedekah bumi di Desa Plesungan sebelum menjadi desa wisata. Pertama, sebagai agenda tahunan wisata Plesungan BUMDes mengadopsi tradisi setempat menjadi sedekah bumi yang masyarakat sekitar kenal dengan resik deso. Kedua, tujuan akhir yang berbeda sedekah bumi untuk mengingatkan pajak bumi resmi atau PBB (Pajak Bumi dan Bangunan) dan resik deso untuk melanggengkan tradisi 
yang telah ada sejak nenek moyang. Ketiga, masyarakat Plesungan mayoritas adalah masyarakat urban maka peneliti mencari makna dari pelaksanaan tradisi yang masih berjalan. Diharapkan dengan penelitian ini pembaca mendapat edukasi tentang sejarah, makna juga nilai pada tradisi sedekah bumi dan dapat ikut mengkritisi perubahan budaya yang terjadi pada tradisi sedekah bumi atau resik deso di era modern saat ini.

\section{Metode}

Bentuk penelitian ini adalah penelitian kualitatif. Peneliti menafsirkan fenomena sedekah bumi meliputi sejarah, pelaksanaan tradisi, nilai tradisi, hubungan tradisi dengan era modernisasi masa kini untuk mencari gambaran eksistensi dari sedekah bumi di Desa Plesungan. Maka dari itu, peneliti menginterpretasikan dan menggali data yang diperoleh mengenai eksistensi tradisi sedekah bumi pada era modern saat ini dengan melihat perubahan sosial budaya menggunakan teori akulturasi. Menurut Gillin dan Gillin (Roszi \& Mutia, 2018), asimilasi dan akulturasi dapat terjadi apabila adanya: (1) kesetian dan keserasian sosial; (2) kesempatan dalam bidang ekonomi; (3) persamaan kebudayaan; (4) perkawinan campur; dan (5) adanya ancaman dari luar.

Obyek dan masalah penelitian mempengaruhi pertimbangan mengenai pendekatan, desain ataupun metode penelitian yang diterapkan (Bachri, 2010). Pendekatan penelitian yang digunakan adalah penelitian deskriptif. Peneliti menekankan pada catatan dengan deskripsi menggunakan kalimat rinci dan mendalam tentang bagaimana proses hingga pemaknaan yang menggambarkan situasi yang sebenarnya guna mendukung penyajian data (Moleong, 2019).

Dalam sumber data penelitian ini peneliti menggunakan kata-kata dan tindakan sebagai sumber data utama dan sumber data tertulis seperti sumber buku, jurnal ilmiah, arsip atau dokumen dan sebagainya. Peneliti mencari data utama dari wawancara yang dilakukan kepada 3 narasumber utama, yaitu 2 orang yang dianggap sesepuh desa dan 1 orang dari kepala RT dengan narasumber pendukung warga sekitar Dukuh Samirukun Desa Plesungan. Dengan sumber data tertulis jurnal tentang sedekah bumi dan data statistik kelurahan Plesungan.

Teknik pengumpulan data yang digunakan dalam penelitian ini adalah observasi di desa wisata Plesungan, Gondangrejo, Karanganyar yang menyangkut tentang sedekah bumi atau resik deso seperti mengamati pelaksanaan tradisi, mengamati perkembangan desa dan lain lain. Wawancara dilakukan pada informan terpilih, seperti sesepuh desa Plesungan juga sesepuh yang mengikuti pelaksanaan ritual sedekah bumi/ resik deso. Dokumentasi, berupa foto meliputi pelaksanaan tradisi, keadaan Desa Plesungan dan lain-lain.

Dalam proses analisis data peneliti menggunakan tiga tahap yaitu reduksi data, penyajian data dan penarikan kesimpulan. Setelah peneliti mencari data kemudian data tersebut direduksi dengan dipandu oleh tujuan yang akan dicapai sehingga dapat memperjelas data yang akan digunakan agar sesuai dengan fokus permasalahan. Dalam hal ini setelah peneliti mendapat segala data melalui wawancara maupun dari dokumen terkait Sedekah Bumi di Desa Wisata Plesungan, peneliti akan memilah mana yang data kurang perlu dan mencari hal-hal pokok agar penarikan kesimpulan dapat menjawab masalah. Selanjutnya penyajian data, peneliti menemukan pola hubungan sehingga memberi gambaran secara menyeluruh dari penelitian tentang Sedekah Bumi tersebut. Langkah terakhir penarikan kesimpulan. Rangkain analisis penelitian dapat dilihat pada gambar 1 berikut.

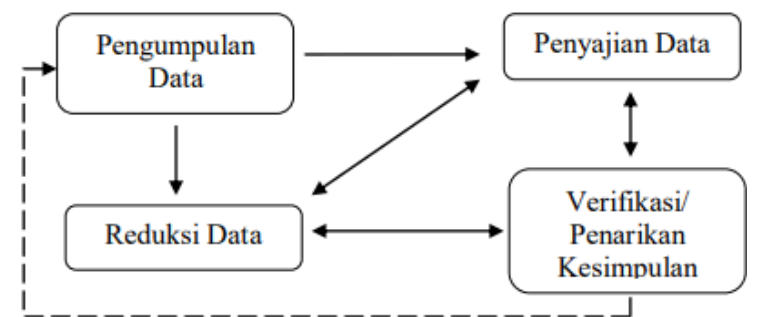

Gambar 1. Pola analisis data 


\section{Hasil dan Pembahasan}

\subsection{Konteks Geografis Desa Plesungan}

Desa Plesungan adalah salah satu desa yang berada di Kabupaten Karanganyar. Desa Plesungan ini terdiri dari 6 dusun yaitu Blembem, Grumbulpring, Tunggulrejo, Ngrancang, Ingasrejo, Dalon dan memiliki 14 dukuh terdiri dari Blembem, Bonorejo, Bonoroto, Dalon, Grumbulpring, Gulon, Ingasrejo, Jengglong, Mojorejo, Ngrancang, Plesungan, Samirukun, Tunggulrejo dan Wirun. Desa Plesungan mempunyai batas wilayah seperti pada gambar 2, sebelah Utara yaitu Desa Jeruksawit, sebelah Barat adalah Desa Wonorejo, sebelah Selatan Kelurahan Mojosongo Kotamadya Surakarta, sebelah Timur adalah Sungai Bengawan Solo. Luas Desa Plesungan Kecamatan Gondangrejo adalah 597,5195 Ha dengan jumlah penduduk 9.064 dan 2764 kepala keluarga.

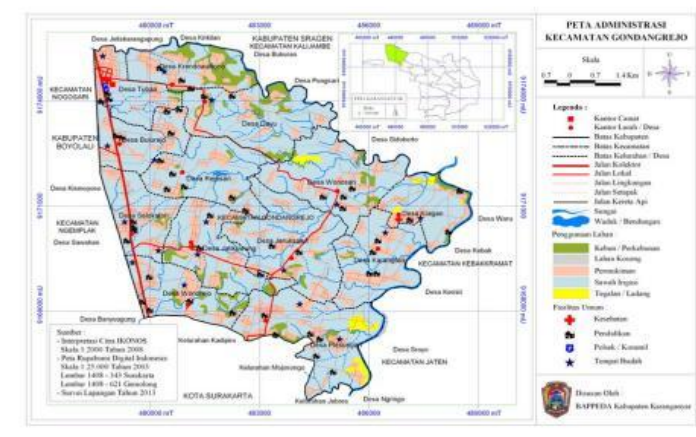

Gambar 2. Peta lokasi Kecamatan Gondangrejo

Dengan jumlah penduduk di Kelurahan Plesungan menurut jenis kelamin dan golongan umur sesuai data monografi triwulan Desember 2020 tercatat 9.064 jiwa dengan jumlah laki-laki 4.633 jiwa dan perempuan 4.431 jiwa. Penduduk dengan usia 0-15 tahun 2.190 jiwa, Penduduk dengan usia 15-65 tahun adalah 6.282 jiwa. Penduduk dengan usia 65 tahun keatas adalah 592 jiwa.

Sebagian besar penduduk Desa Plesungan bermatapencaharian swasta yaitu sebanyak 2.454 orang. Kemudian disusul oleh masyarakat yang bermatapencaharian wiraswasta atau berdagang yaitu sebanyak 687 orang. Lalu dilanjutkan oleh masyarakat yang bermatapencaharian tukang bangunan sebanyak 387 orang, petani dengan jumlah 239 orang, peternak 156 orang, buruh tani dengan jumlah 142 orang, pengrajin dengan jumlah 98 orang, bekerja dijasa 87 orang, PNS dengan jumlah 81 orang, pensiunan dengan jumlah 39 orang, pekerja seni dengan jumlah 28 orang, TNI/POLRI dengan jumlah 4 orang. Selain itu, terdapat juga masyarakat di Desa Plesungan yang bermatapencaharian selain tersebut diatas yaitu dengan jumlah 563 orang. Secara ringkas penggolongan mata pencaharian masyarakat dapat dilihat pada gambar 3 .

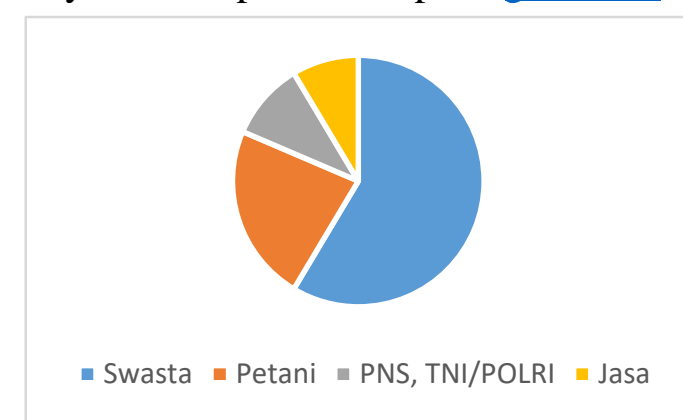

Gambar 3. Diagram lingkaran data pekerjaan masyarakat Plesungan

Tingkat pendidikan di Desa Plesungan dapat dikata tidak terlalu tinggi, hal ini terlihat dari jumlah tamatan perguruan tinggi S1, S2, S3 yang terendah yaitu sebanyak 151 orang untuk akademi/D1-D3 sebanyak 169 orang dari 9.064 orang penduduk. Pendidikan tamat SLTA sebanyak 1.507 orang, pendidikan tamat SMP sebanyak 1.374 orang, pendidikan tamat SD sebanyak 1.569 orang, pendidikan tamat Taman Kanak-Kanak (TK) sebanyak 268 orang, dan yang tidak tamat sekolah sebanyak 158 orang, sedangkan yang tidak bersekolah sebanyak 261 orang. Secara ringkat data dapat dilihat pada gambar 4 berikut.

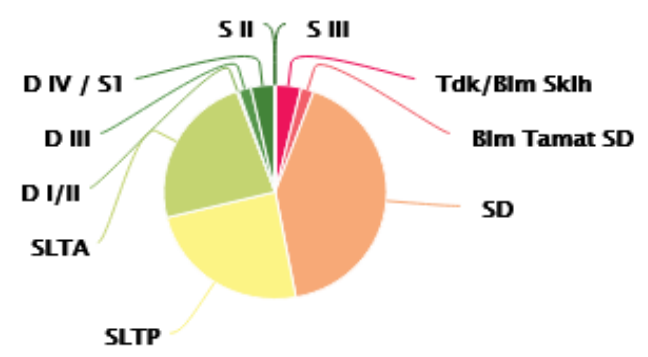

Gambar 4. Diagram lingkaran pendidikan Plesungan 


\subsection{Sejarah Tradisi Sedekah Bumi}

Sedekah bumi merupakan kegiatan berupa selamatan atau pemberian kepada bumi sebagai wujud rasa syukur yang dilaksanakan sesudah panen (Hidayatulloh, 2015). Salah satu penelitian terdahulu yang dilakukan Huda (2017), mengungkapkan bahwa permulaan sedekah bumi tidak ada yang tahu sejak kapan dimulainya, karena mereka hanya menerima dari nenek moyang secara turun menurun. Masyarakat hanya tahu dari tradisi nenek moyangnya saja, tidak tahu asal muasal pelaksanaannya dulu. Begitu juga pada masyarakat Dukuh Samirukun Desa Plesungan, mereka hanya mengetahui bahwa tradisi sedekah ini perlu dilestarikan dan diperkenalkan kepada anak cucu.

Pada masa lalu Desa Plesungan adalah pemukiman yang jarang penduduk, jarak antar rumah sangat jauh masih banyak terdapat sawah dan mayoritas penduduk sekitar adalah petani. Salah satu sesepuh Dukuh Samirukun Desa Plesungan, Purwanto mengatakan sebagai berikut.

\section{“....Petani-petani rumiyin meniko gagal panen gegara hama tikus gandeng walang karo tikus musnah panenane sae lajeng mben taun ngadakne resik deso karo tayuban...." \\ (Petani dulu gagal panen karena hama tikus dan belalang, ketika belalang dan tikus musnah panenan menjadi membaik setiap tahun diadakan "resik deso" dan tayuban)". (Wawancara Purwanto tanggal 10 Maret 2021)}

Petani sering mengalami gagal panen karena hama tikus dan belalang, tetapi tanpa putus asa dan putus doa melimpahlah hasil panen. Petani merasa senang karena melimpahnya hasil panen. DI samping itu juga sebagai wujud syukur yang diharapkan agar tidak terjadi hal buruk satu tahun kedepan maka warga masyarakat berinisiatif untuk melakukan sedekah atau acara selamatan sebagai wujud rasa syukur.
Semenjak itulah diadakan resik deso pada Dukuh Samirukun Desa Plesungan.

Slametan bermakna upacara makan bersama dalam bahasa Jawa sehari-hari. Slametan merupakan suatu upacara pokok atau unsur penting dari hampir semua ritus dan upacara dalam sistem religi orang Jawa pada umumnya seperti sedekah bumi ini. Ada empat jenis slametan, yaitu (1) slametan untuk lingkar hidup seseorang, yang meliputi kelahiran, khitanan, perkawinan, dan kematian; (2) slametan untuk hari-hari raya Islam seperti Maulud Nabi, Idul Fitri, Idul Adha, dan sebagainya; (3) slametan yang diadakan berkaitan dengan integrasi sosial desa; (4) slametan sela, yang diselenggaraan dalam waktu yang tidak tetap, tergantung dengan kejadian luar biasa yang dialami seseorang. Pada tradisi sedekah bumi atau resik deso ini termasuk pada jenis selamatan yang diadakan berkaitan dengan integrasi sosial desa karena tradisi ini menyentuh pada kesejahteraan desa pada bidang pertanian dengan adanya kesuksesan pada bidang tersebut masyarakat mengadakan selamatan untuk mengungkapkan syukur atas hasil panen dan kesejahteraan desa.

Upacara sedekah bumi merupakan salah satu upacara adat berupa prosesi seserahan hasil bumi dari masyarakat kepada alam. Upacara ini biasanya ditandai dengan pesta rakyat yang diadakan di balai desa atau di lahan pertanian maupun tempat-tempat yang dianggap sakral oleh masyarakat. Pelaksanaan sedekah bumi yang digelar di sendang juga sebagai bentuk usaha untuk melestarikan keberadaan sendang yang menjadi awal sejarah adanya cerita desa (Huda, 2017). Pelaksanaan tradisi resik deso atau sedekah bumi ini juga dilaksanakan di Sendang Plesungan untuk mengenang bagaimana sejarah Desa Plesungan.

"yo mbau rekso kui saking sesepuh, cikal bakal pertama niku asmanipun Eyang Kiyoso lan iku ndamel sendang meniko pas niki tesih alas, ndados sendang niku amargi ngelak lajeng medal sumber e terus diuri-uri ngasi sak 
niki sendang Plesungan terus dilestarikake" (ya dikenalkan dari sesepuh, nenek moyang pertama bernama Eyang Kiyoso dan membuat sendang ini ketika masih berupa hutan, menjadi sendang karena kehausan kemudian keluar dari sumbernya dan terus mengisi Sendang Plesungan ini terus sampai dilestarikan". (Wawancara Purwanto pada tanggal 15 Maret 2021).

Upacara ini sudah berlangsung turun termurun dari nenek moyang dan berkembang di Pulau Jawa, terutama di wilayah yang kuat akan budaya agraris (Afif, 2014). Jadi, sedekah bumi adalah tradisi turun temurun dari nenek moyang pada budaya agraris sebagai rasa pengucapan syukur atas berkah panen. Untuk pelaksanaan tradisi resik deso ini selalu dilaksanakan setelah panen padi atau bahasa sesepuh di sana "wayah padang" untuk bulan pelaksanaan sekitar bulan AgustusSeptember. Dahulu tradisi sedekah bumi atau resik deso Dukuh Samirukun Desa Plesungan hanya sekadar bancaan atau tumpengan untuk mengenang kondure (kembalinya) Dewi Sri.

\subsection{Tata Cara Pelaksanaan Sedekah Bumi}

Sedekah bumi pada masyarakat desa Plesungan lebih dikenal dengan tradisi resik deso. Pada masyarakat Desa Plesungan tradisi ini telah ada sejak lama dan diturunkan secara turun-temurun dari nenek moyang. Masyarakat masih melaksanakannya sebagai wujud rasa syukur atas hasil panen yang diterima meskipun mayoritas masyarakat Desa Plesungan tidak bekerja sebagai petani. Tradisi ini masih berjalan setiap tahunnya. Pelaksanaan tradisi ini dilakukan oleh dusun yang masih menjaga kelestarian tradisi. Salah satunya Dukuh Samirukun. Dukuh ini terdiri dari 3 RT dan masih mempertahankan tradisi dengan beberapa ritual yang ada sejak turun temurun. Untuk dukuh yang lain di desa Plesungan tradisi resik deso atau sedekah bumi ini hanya dengan kenduri dan doa bersama saja.

Pelaksanaan tradisi resik deso dimulai pada 3 hari sebelum pelaksanaan tradisi atau puncak ritual. Pelaksanaan tersebut yaitu bersih-bersih sendang atau biasa disebut "resik sendang", yang dilakukan oleh para laki-laki masyarakat sekitar. Resik sendang ini selalu dilakukan pada Jumat Kliwon yang pada kepercayaan jawa ini hari ini hari yang keramat atau suci.

Sebelum hari pelaksanaan tradisi pada pagi hari dilaksanakan bersih dusun dengan pembersihan desa bersama warga masyarakat Desa Plesungan. Laki-laki bertugas membersihkan sekitar jalan kampung dan para perempuan membersihkan bagian dalam rumah. Lalu, pada malam diadakan pengajian atau "midodareni" berisi doa bersama agar pelaksanaan tradisi keesokan hari berjalan dengan lancar. Pada hari pelaksanaan dimulai atau puncak ritualnya, pagi hari dimulai dengan kirab.

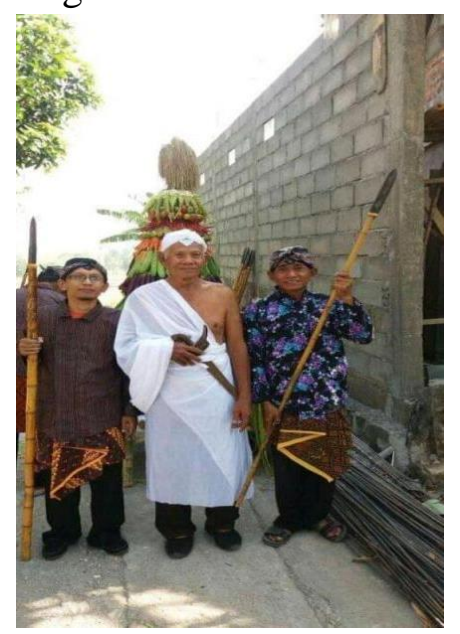

Gambar 5. Posisi barisan terdepan pada Kirab Dukuh Samirukun (Sumber: Dokumentasi penulis)

Terlihat pada gambar 5 gambaran posisi barisan saat pelaksanaan kirab tradisi resik deso pada Dukuh Samirukun Desa Plesungan. Baris terdepan adalah sesepuh yang bertugas untuk mendoakan tumpeng utama yang memiliki tinggi kurang lebih satu meter dan mendoakan leluhur yang dikenal dengan nama Eyang Kiyoso. Baris kedua berpakaian seperti prajurit yang berada di belakang sesepuh bagian kanan 
dan kiri diikuti barisan belakang adalah pembawa tumpeng utama yang dibawa oleh 4 orang. Barisan selanjutnya ada para putra putri remaja desa Plesungan dan diikuti barisan selanjutnya adalah masyarakat umum.

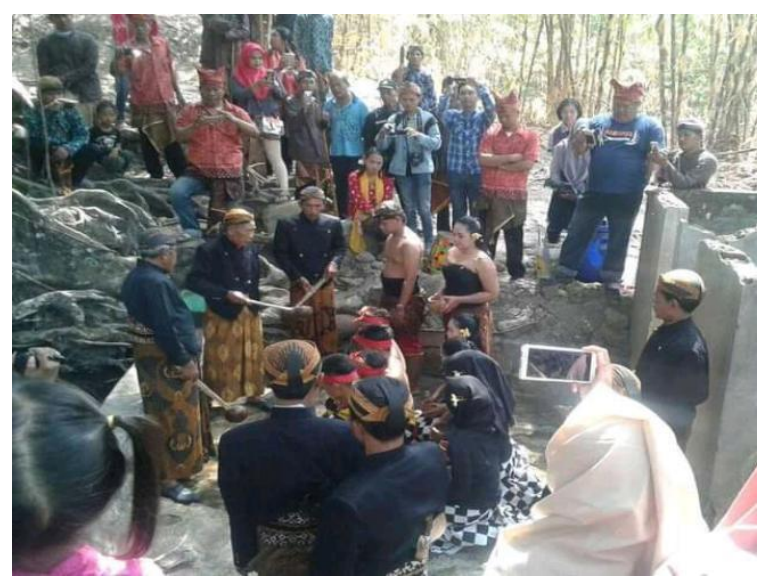

Gambar 6. Prosesi siraman kepada pemuda pemudi Dukuh Samirukun (Sumber: Dokumentasi penulis)

Pada gambar 6 tampak prosesi "siraman" ketika sesampainya pada Sendang Plesungan. Prosesi ini dilakukan kepada pemuda pemudi Dukuh Samirukun oleh sesepuh.

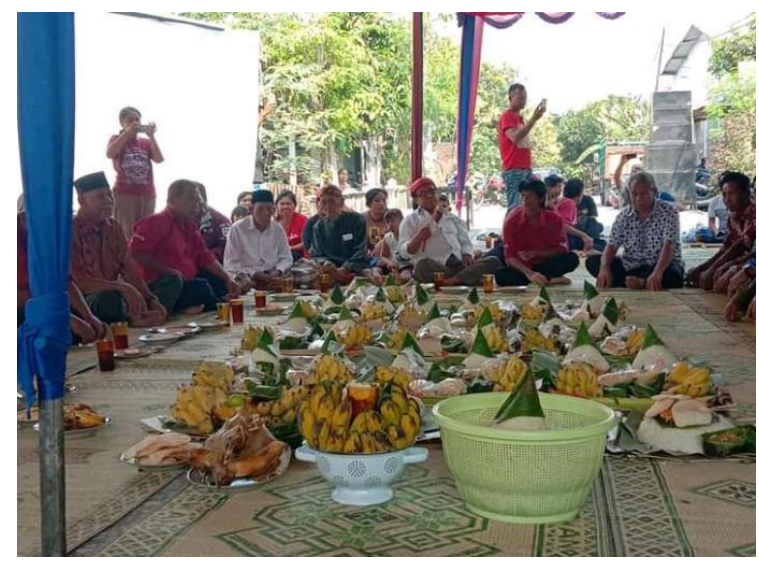

Gambar 7. Suasana makan tumpeng bersama di Sendang Plesungan (Sumber: Dokumentasi penulis)

Pada gambar 7 tampak suasana makan bersama hasil bumi yang dibawa masingmasing kepala keluarga Dukuh Samirukun Desa Plesungan ketika kirab dilakukan. Tumpeng yang dibawa seperti buah-buahan dan sayur-sayuran, tidak ada patokan untuk apa yang harus dibawa pada tradisi sedekah bumi atau resik deso ini. Setelah makan bersama pada zaman dulu terdapat acara tayuban atau tari-tarian dengan saweran untuk para tayub (penari) karena seiring berjalan waktu dan penyesuaian global hanya pertunjukan tari daerah tanpa ada saweran.

Seiring berjalannya waktu, Desa Plesungan menjadi desa wisata dan terbentuk wisata Plesungan. BUMdes mengadopsi tradisi resik deso menjadi sedekah bumi dengan harapan masyarakat mengenal tradisi sedekah bumi dan mengenal budaya Jawa agar tetap terjaga oleh masyarakat Desa Plesungan. Selain itu, juga untuk mengingatkan pajak bumi atau PBB. Adapun pelaksanaan tradisi sedekah bumi pada wisata Plesungan ini berjalan selama tiga hari. Sebelum pelaksanaan tradisi sedekah bumi didatangkanlah pemungut pajak agar masyarakat setempat membayar pajak atau PBB terlebih dahulu.

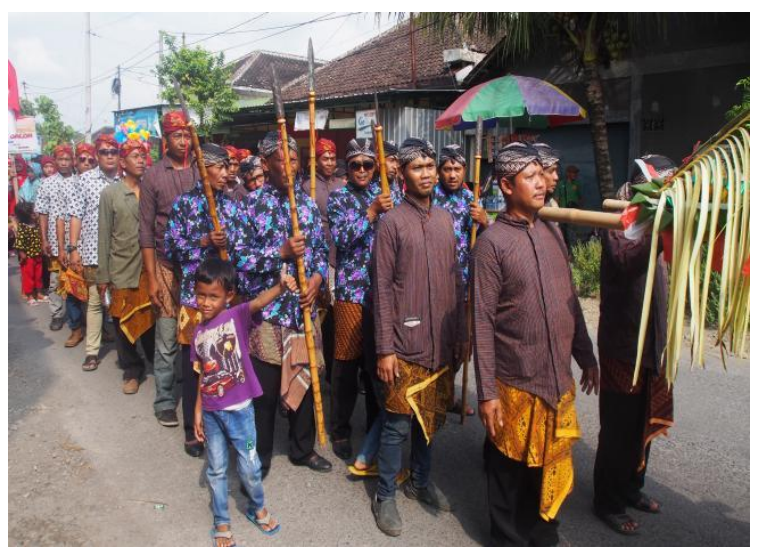

Gambar 8. Suasana kirab oleh satu satu perwakilan dukuh di Desa Plesungan (Sumber: Dokumentasi penulis)

Gambar 8 menunjukkan suasana kirab yang diikuti oleh masyarakat Plesungan yang terdiri dari 6 dusun dan 11 dukuh dari Desa Plesungan. Kirab ini dimulai dari Kelurahan Plesungan dan diakhiri di wisata Plesungan.

Gambar 9 merupakan kegiatan kajian oleh pemuka agama Islam. Selain kajian dari pemuka agama, terdapat sambutan dari kepala BUMdes dan kepala desa. Setelah itu, acara penilaian tumpeng yang dibawa setiap dukuh. 


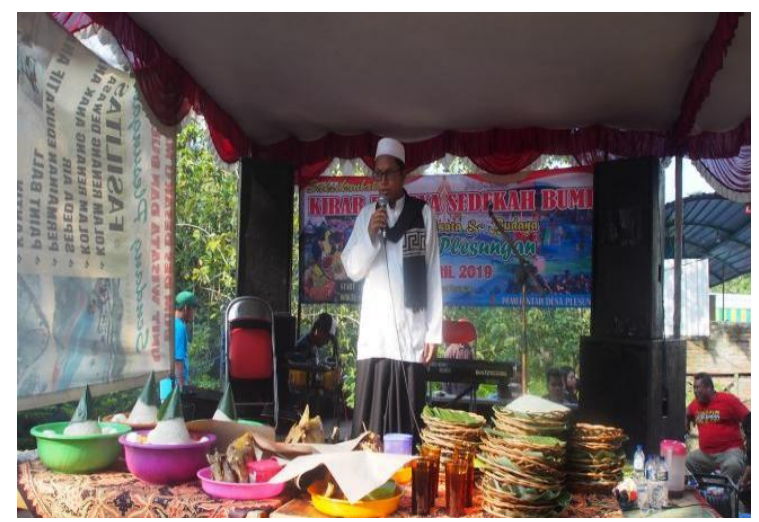

Gambar 9. Kajian oleh pemuka agama (Sumber: dokumentasi penulis)

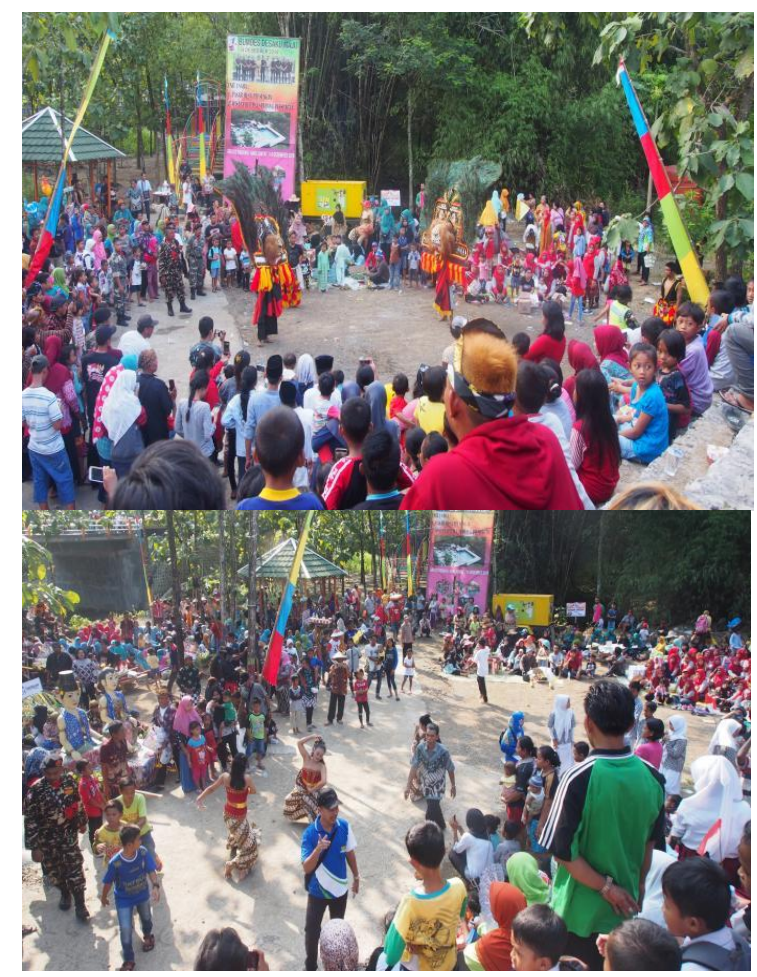

Gambar 10. Suasana pertunjukan yang dibawakan oleh salah satu perwakilan dukuh

(Sumber: dokumentasi penulis)

Gambar 10 merupakan suasana akhir acara sedekah bumi pada Wisata Plesungan yang dikelola oleh BUMDes yaitu pertunjukan seni dan makan bersama dari hasil bumi yang dibawa masing-masing dukuh. Puncak acara dari sedekah bumi yang diadakan wisata Plesungan adalah pengumumam pemenang lomba-lomba.

Setiap budaya pasti mengalami perubahan seiring berjalannya waktu, tradisi dihadapkan dengan berbagai macam kendala atau tantangan baik dari dalam atau luar dari budaya itu sendiri. Masyarakat desa Plesungan mengalami perubahan tradisi yang cukup signifikan sejak dua tahun yang lalu karena adanya pandemi COVID-19 yang bersifat global ini. Pandemi ini adalah suatu penyakit oleh virus menular yang disebabkan melalui droplet (percikan air liur) yang dihasilkan saat orang terinfeksi batuk, bersin ataupun menghembuskan nafas. Jadi banyak unsur pada tradisi sedekah bumi atau resik deso yang dihilangkan karena pada beberapa kegiatan seperti kirab dan pertunjukan seni. Kegiatankegitan tersebut tidak dilakukan karena sifatnya berkerumun yang menyebabkan mudahnya penyebaran virus. Jadi selama dua tahun semenjak pandemi COVID-19 masuk di Indonesia tradisi di Desa Plesungan terlebih dukuh Samirukun hanya berupa kendurinan dengan doa bersama dan pembawaan tumpeng sebagai hasil bumi dan wujud syukur. Untuk sedekah bumi di wisata Plesungan tidak diadakan sama sekali karena memang larangan dari pemerintah setempat.

\subsection{Transformasi Sedekah Bumi}

Sedekah bumi adalah salah satu tradisi yang masih dilestarikan warga Desa Plesungan tetapi tidak semua dusun melakukan tradisi tersebut, hanya beberapa dusun yang masih mempertahankan tradisi tersebut. Tradisi sedekah bumi atau resik deso ini masih dilakukan hingga sekarang dan menjadi tradisi tahunan yang wajib dilaksanakan karena masyarakat percaya dan khawatir jika akan terjadi sesuatu jika pelaksanaan tradisi tidak dilaksanakan. Istilah tradisi sedekah bumi baru diperkenalkan atau diperbincangkan setelah terbentuknya desa wisata oleh BUMdes Plesungan karena sesepuh dulunya menamakan sedekah bumi ini adalah resik deso. Menurut sesepuh yang ada di Desa Plesungan mengatakan jika kedua istilah ini adalah sama.

Menurut Sagi Prapto Wiyono sedekah bumi sebagai berikut.

“...sedekah bumi nggeh bersih dusun kangge kampung kan bersih dusun nek 
desa niku sedekah bumi..." (Sedekah bumi ya bersih dusun untuk kampung jika desa itu sedekah bumi). (Wawancara Sagi Prapto Wiyono tanggal 12 April 2021).

Dari pernyataan di atas sedekah bumi dan resik deso adalah sama perbedaanya jika sedekah bumi ini dikelola oleh kelurahan dan tujuannya untuk menyedekahkan wisata. Sedangkan resik deso, diadakan satu dusun untuk menyedekahkan desa. Waktu pelaksanaannya berbeda, sedekah bumi diadakan setiap April dan untuk resik deso pelakasanaannya pada pra-panen. Jadi yang membedakan adalah sedekah bumi di wisata Plesungan dikelola oleh kelurahan atau panitianya dari kelurahan Plesungan dan untuk resik deso terlebih di Dukuh Samirukun dikelola oleh karang taruna setempat.

Eksistensi Tabuik di tengah-tengah masyarakat telah terkontaminasi dan terganggu oleh desakan daerah, pariwisata, dan otoriter pemerintahan (Dalmeda \& Elian, 2017). Seperti pernyataan tersebut, untuk pengelolaan tradisi Desa Plesungan juga ditangani oleh lembaga pemerintahan seperti BUMDes Plesungan maka akan ada pembaharuan-pembaharuan di dalam tradisi yang disesuaikan dengan nilai norma masa kini. Meskipun begitu hanya pelaksanaannya dan sedikit unsur di dalamnya yang berubah seperti adanya perlombaan hias tumpeng juga pertunjukan seni sebagai ajang kontes setiap dukuhnya, untuk resik deso tidak ada dan untuk ritual pokok seperti kirab juga tumpengan tidak tersentuh oleh pembaharuan, karena konsep akulturasi tidak menghilangkan unsur aslinya. Perbedaan lain terletak pada sebelum hari pelaksanaan sedekah bumi di Wisata Plesungan tidak ada "midodareni" atau pengajian tetapi untuk resik deso ada.

Sejumlah organisasi kemasyarakatan mengadakan perbaikan dan rehabilitasi rekonstruksi pembangunan yang terprogram yang menjadikan pola pikir masyarakat berbeda dari sebelumnya. Budaya adalah induk dari tradisi, seiring perkembangan zaman karena adanya mobilitas, teknologi yang semakin canggih, terbukanya pemikiran masyarakat atas pembaharuan dan penyesuaian nilai norma yang terjadi pada lingkup sosial masyarakat membuat tradisi seolah harus dapat menyesuaikan. Tahap pola budaya atau perilaku sosial cenderung berbeda dengan sebelumnya dan hasil dari kebiasaan atau pola budaya baru yang kemudian memberi celah pembaharuan semacam akulturasi. Dukungan dari organisasi kemasyarakatan setempat adalah salah satu wujud pendorong akulturasi seperti diadopsinya resik deso menjadi sedekah bumi yang membawa beberapa unsur penambahan tetapi tetap mempertahankan unsur utama yaitu kirab dan tumpengan.

Sedekah bumi di wisata Plesungan lebih kepada alat penarik wisatawan juga mengenalkan tradisi di Desa Plesungan dan tujuan resik deso untuk menghindarkan dari malapetaka, melestarikan tradisi yang sudah ada sejak nenek moyang dan juga untuk mengenalkan tradisi kepada penerus di masyarakat Dukuh Samirukun Desa Plesungan. Dengan melihat tujuan tradisi dari sedekah bumi di wisata Plesungan terdapat faktor kesempatan dalam bidang ekonomi yang diolah oleh BUMDes karena jika wisatawan tertarik akan melirik bagaimana potensi wisata pada Wisata Plesungan tersebut. Jadi dengan diperkenalkannya tradisi sedekah bumi dan dikemas sesuai dengan kebutuhan modern ini dapat membuka peluang ekonomi dan hal tersebut termasuk pada faktor pendorong akulturasi yang disampaikan oleh Gillin.

Sedekah bumi di wisata Plesungan selalu diadakan setiap bulan April karena agenda tahunan yang telah ditetapkan BUMdes pada bulan tersebut untuk mengingatkan pajak bumi atau PBB (Pajak Bumi dan Bangunan). Berbeda hal dengan resik deso yang dikelola dari karang taruna RT setempat dan bukan dari kelurahan. Akan tetapi, hal yang sama adalah tujuannya untuk menghindarkan dari bala, mengucap rasa syukur atas nikmat yang telah diberikan tuhan, dan melestarikan juga mengenalkan tradisi setempat. 
Terbentuknya proses akulturasi adalah adanya keseragaman (homogenity), seperti nilai baru yang tercerna akibat keserupaan tingkat dan corak budayanya. Kemudian syarat fungsi, seperti nilai baru yang diserap hanya sebagai suatu manfaat yang tidak penting atau hanya sekedar tampilan (Roszi \& Mutia, 2018). Terlihat keseragaman pada dua konsep tradisi sedekah bumi dan resik deso ini dengan melihat nilai, makna dan tujuannya.

\subsection{Antusias Masyarakat terhadap Tradisi Sedekah Bumi}

Suatu tradisi akan tetap terjaga dan langgeng jika berfungsi dengan baik. Begitu pula dengan tradisi sedekah bumi atau resik deso di Desa Plesungan. Masyarakat sekitar masih peduli dan yakin akan kelanggengan tradisi ini karena menurut mereka tradisi ini memberikan nilai-nilai yang baik seperti gotong royong, kebersamaan, kerukunan, dan juga bentuk rasa syukur. Tradisi sedekah bumi merupakan salah satu bentuk ritual yang dilakukan oleh masyarakat petani, mereka menggantunggkan hidupnya dengan memanfaatkan kekayaan alam yang ada di Bumi. Bagi masyarakat Jawa khususnya para petani, tradisi ritual tahunan semacam sedekah bum ini bukan hanya sebagai rutinitas belaka, akan tetapi memiliki makna yang lebih dari itu, yakni sebagai bentuk penghormatan kepada Tuhan atas limpahan rezeki lewat pertanian.

Selain itu, tradisi sedekah bumi sebagai bentuk pengenalan sejarah terbentuknya Desa Plesungan bagi para penerus anak cucu dan juga bentuk tindakan menjauhkan dari bala atau hal-hal buruk salah satunya gagal panen. Menurut Purwanto sebagai berikut.

“..o mboten saget do percoyo gegeblug niku esuk loro sore mati niku mboten wani..." (tidak bisa semua percaya bencana itu pagi sakit sore meninggal) (Wawancara Purwanto tanggal 10 Maret 2021).

Dari pernyataan tersebut mayarakat Desa Plesungan masih melestarikan tradisi resik deso ini dan adanya pemikiran dan penanaman dalam hati akan terjadi hal di luar nalar yang akan menimpa warga jika tradisi dilupakan. Seperti pada penelitian terdahulu di Desa Tebang Kacang bahwa tradisi sedekah bumi merupakan babat alas atau ungkapan pembersihan diri. Masyarakat percaya jika tradisi tidak dilakukan akan terjadi suatu hal yang tidak diinginkan seperti gagal panen atau hal kurang baik lainnya. Meskipun belum pernah terjadi, masyarakat tetap melaksanakan tradisi tersebut dari tahun ke tahun. Masyarakat yakin adanya Allah, yakin bahwa Muhammad adalah utusan Allah, yakin adanya Nabi-Nabi lain, yakin adanya tokohtokoh Islam yang keramat, tetapi mereka juga yakin adanya roh-roh tertentu yang menguasai bagian-bagian dari alam semesta, seperti adanya makhluk- makhluk halus penjelmaan nenek moyang atau orang yang sudah meninggal, adanya roh-roh penjaga tempat tertentu, dan lain sebagainya dan masyarakat Desa Plesungan masih melestarikan sebagai bentuk penghormatan terhadap tradisi yang telah ada sejak turuntemurun.

Pemikiran baik yang diajarkan oleh para sesepuh bahwa tradisi sedekah bumi atau resik deso ini untuk untuk mengucap syukur dan menghindarkan dari bala. Di samping hal tersebut tradisi ini juga terdapat unsur hiburan yang membuat warga merasa senang yaitu tayuban.

Senada dengan hal tersebut menurut Ari Wisnumurti sebagai berikut.

“...soal itu kita cerita dulu ya awal dulu saya kecil ini desa ini masih 1 RT belum dipecah seperti seperti sekarang nah justru disitu kelihatan terasa sekali sakralnya, persatuan, kesatuan, gotong royong, karena semua penduduk masih pribumi masih memiliki 1 tujuan yang sama tapi dengan perkembangan zaman adanya pendatang otomatis tidak semua murni, ya ikut tapi tidak merasakan dalam arti lainnya mengikuti juga ada yang pro kontra itu tadi pasti ada tetapi tetap memberi masukan secara baik..." 
(Wawancara Ari Wisnumurti tanggal 23 Maret 2021).

Masyarakat Desa Plesungan antusiasnya berbeda antara dahulu dan sekarang. Dahulu masyarakat sangat menanti hiburan tayuban tetapi sekarang karena tayuban diganti dengan tari-tarian seperti pada umumnya euforia masyarakat menjadi berkurang. Tayuban merupakan salah satu kesenian tradisi rakyat. Kesenian Tayuban pada awal kelahirannya adalah untuk persembahan kesuburuan pertanian. Meskipun kini kesenian tayuban sudah beralih fungsi, namun konteks dari fungsinya tersebut sama yaitu dalam kesuburan. Kesuburan di dalam pertanian berarti kesuburan akan tanah yang ditamani oleh padi, sehingga hasil panennya akan melimpah.

Selain itu masyarakat pendatang membuat kesakralan dari tradisi ini berkurang karena banyak yang tidak memaknainya dengan sepenuh hati, kurang mengerti tentang tradisi, dan kurang mengerti makna sejarah pada Desa Plesungan. Akan tetapi, banyak hal baik yang membuat masyarakat tetap melestarikan tradisi ini diantaranya menanamkan nilai baik untuk selalu bersyukur, selalu menghargai makanan yang diberikan Tuhan, dan nilai kebersamaan juga gotong royong. Dari kesetian dan keserasian sosial yang terjadi, masyarakat masih mempertahankan tradisi meskipun terjadi perubahan sosial budaya yang disesuaikan dengan era modern ini. Terlihat adanya proses akulturasi di dalamnya yaitu hilangnya tayuban karena disesuaikan dengan nilai norma yang berlaku pada masyarakat sekarang.

Untuk sedekah bumi di Wisata Plesungan menurut Ari Wisnumurti sebagai berikut.

“...kalau itu tergantung persepsi masingmasing menurut saya yang wisata Plesungan diharap dapat mendongkrak juga mengenalkan budaya dari wisata Plesungan dengan dikemas hiburan juga perlombaan tumpeng jadi nilai kesakralannya menurut saya kurang. Tapi, jika di Samirukun sendiri tujuan masih sama yaitu untuk melestarikan adat budaya sebagai wujud rasa syukur kepada tuhan..." (Wawancara Ari Wisnumurti tanggal 23 Maret 2021).

Tradisi sedekah bumi yang dilaksanakan di wisata Plesungan menarik banyak perhatian warga sekitar karena memang dari 6 dusun diwajibkan untuk mengikuti tradisi dan hiburan-hiburan yang disuguhkan dari berbagai dukuh di Desa Plesungan membuat perayaan semakin meriah dan menarik untuk dinikmati. Perayaan tradisi sedekah bumi yang diadakan selama dua tahun sebelum pandemi COVID-19 jika melihat antusias masyarakat mengalami peningkatan di tahun kedua.

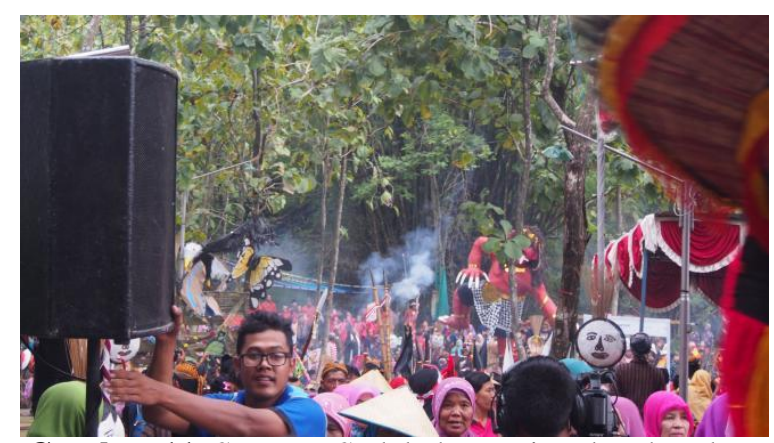

Gambar 11. Suasana Sedekah Bumi pada tahun ke2 (Sumber: Dokumentasi penulis)

Gambar 11 menunjukkan suasana tradisi sedekah bumi pada Wisata Plesungan yang dinilai lebih meriah dari tahun sebelumnya karena ditandai dengan semakin kreatifnya masyarakat Desa Plesungan yang mengikuti perlombaan dan semakin banyak warga dari luar Desa Plesungan yang datang menyaksikan, seperti dari warga Mojosongo dan Banjarsari. Kreativitas dan berbagai inovasi seperti bervariasinya macam lomba dan adanya iringan ogoh-ogoh atau patung raksasa membuat wisatawan semakin mengenal Wisata Plesungan. Hal ini adalah salah satu faktor pendorong akulturasi yang disampaikan oleh Gillin tentang kesempatan dalam bidang ekonomi (Roszi \& Mutia, 2018). 


\section{Kesimpulan}

Tradisi sedekah bumi telah menjadi aset budaya pada masyarakat Jawa terutama pada masyarakat Desa Plesungan, Kecamatan Gondangrejo, Kabupaten Karanganyar. Tradisi sedekah bumi dilaksanakan sebagai wujud rasa syukur kepada tuhan atas limpahan rahmat akan hasil bumi. Pada era modern saat ini suatu budaya atau tradisi harus disesuaikan dengan arus global agar kelanggengan dari suatu budaya atau tradisi tetap terjaga.

Berdasakan hasil analisis, sedekah bumi di Wisata Plesungan diadopsi dari resik deso yang tujuannya sama untuk membayar pajak, mengucap syukur, dan juga melestarikan tradisi. Dalam tradisi tersebut terdapat beberapa unsur yang berbeda dari waktu pelaksanaan, pelaksanaan ritus, dan adanya perlombaan pada sedekah bumi yang di tradisi resik deso tidak ada, meskipun begitu tujuannya tetap sama. Beberapa perbedaan tersebut disesuaikan dengan arus modernisasi saat ini yang mayoritas masyarakatnya adalah masyarakat urban.

Berdasarkan studi yang dilakukan dapat dipahami bahwa masyarakat Dukuh Samirukun Desa Plesungan tetap melestarikan tradisi sedekah bumi dengan baik meskipun masyarakat telah mengalami perubahan menjadi masyarakat urban. Disamping itu pula dengan adanya sedekah bumi pada wisata Plesungan dapat membuka mata bagi para generasi muda dan wisatawan, disisi lain tradisi ini mendorong kesempatan ekonomi pada masyarakat sekitar Wisata Plesungan, selain itu pula tradisi ini memberikan nilainilai luhur seperti gotong royong dan kebersamaan. Hasil penelitian ini diharapkan dapat mengedukasi pembaca terkait tradisi yang dikaitkan dengan penyesuian perubahan sosial karena terjadinya arus modernisasi.

Dari simpulan di atas, maka saran yang dapat dijabarkan peneliti setelah melaksanakan penelitian sebagai berikut. Pertama, diharapkan sesepuh desa dan tokoh masyarakat terus memberikan edukasi kepada generasi penerus juga warga masyarakat tentang makna, sejarah juga tradisi yang telah dilestarikan sejak turun-temurun ini. kedua, warga masyarakat Desa Plesungan diharap dapat terus melestarikan tradisi sedekah bumi atau resik deso ini supaya budaya Jawa tidak hilang seiring berkembangnya zaman. Ketiga, untuk Dinas Pariwisata serta Dinas Pendidikan dan Kebudayaan, BUMdes dan elemen pemerintahan telah mengapresiasi dengan baik tradisi ini setelah diadopsinya sedekah bumi di Wisata Plesungan diharapkan dapat selalu mendukung dan mengapresiasi juga memberikan ide-ide agar tradisi ini tetap terjaga. Selain itu agar salah satu kekayaan dari kearifan lokal Indonesia ini tidak hilang seiring berkembang dan majunya zaman.

\section{Daftar Pustaka}

Afif. (2014). Sedekah bumi. https://petabudaya.belajar.kemdikbud.g o.id/Repositorys/sedekah_bumi/

Alkaf, M. (2013). Tari sebagai gejala kebudayaan: Studi tentang eksistensi tari rakyat di Boyolali. KOMUNITAS: International Journal of Indonesian Society and Culture, 4(2), 125-138. https://doi.org/10.15294/komunitas.v4i 2.2401

Arinda, I. Y. (2016). Sedekah bumi (Nyadran) sebagai konvensi tradisi Jawa dan Islam mayarakat Sraturejo Bojonegoro. El Harakah Tahun 2014, Vol.16 No. https://doi.org/10.18860/el.v16i1.2771

Astuti. (2019). Eksistensi budaya Rimpu masyarakat Suku Mbojo di Kabupaten Bima. JUPE: Jurnal Pendidikan Mandala, 4(5), 276-280. http://dx.doi.org/10.36312/jupe.v4i5.84 3

Bachri, B. S. (2010). Meyakinkan validitas data melalui triangulasi pada penelitian kualitatif. Teknologi Pendidikan, 10, 46-62. 
http://yusuf.staff.ub.ac.id/files/2012/11/ meyakinkan-validitas-data-melaluitriangulasi-pada-penelitiankualitatif.pdf

Cholifah, U. (2013). Eksistensi grup musik kasidah "Nasida Ria" Semarang dalam menghadapi modernisasi. KOMUNITAS: International Journal of Indonesian Society and Culture, 3(2), 131-137.

https://doi.org/10.15294/komunitas.v3i 2.2309

Dalmeda, M., \& Elian, N. (2017). Makna tradisi Tabuik oleh masyarakat Kota Pariaman (Studi deskriptif interaksionisme simbolik). Jurnal Antropologi: Isu-Isu Sosial Budaya, $18(2)$, 135. https://doi.org/10.25077/jantro.v18i2.6 3

Firmansyah, R. (2016). Konsep dasar asimilasi dan akulturasi dalam pembelajaran budaya. Tidak TKonsep Dasar ASIMILASI \& AKULTURASI Dalam Pembelajaran BUDAYA, December.

https://www.researchgate.net/publicatio n/311718551_Konsep_Dasar_ASIMIL ASI_AKULTURASI_dalam_Pembelaj aran_BUDAYA

Fitri, M., Mangkurat, U. L., Fauziyah, N., \& Mangkurat, U. L. (2018). PASAR TERAPUNG , EKSISTENSI BUDAYA LOKAL BANJARMASIN DI ERA Lomba Karya Tulis Ilmiah Nasional Jember Social and Political Days 2018 Disusun oleh: Nurul Fauziyah Fathurrahman. April 2020. https://www.researchgate.net/publicatio n/340470942_PASAR_TERAPUNG_E KSISTENSI_BUDAYA_LOKAL_BA NJARMASIN_DI_ERA_REVOLUSI_ INDUSTRI_40

Guntoro. (2020). Transformasi Budaya Terhadap Perubahan Sosial di Era Globalisasi. Orphanet Journal of Rare
Diseases, 21(1), 1-9. https://jurnal.iainkediri.ac.id/index.php/ asketik/article/view/2122

Hastuti, S., Slamet, S. Y., \& Rakhmawati, A. (2021). Ecological politeness on Sedekah Bumi ceremony in Merapi Mountainside. 553(Iclp 2020), 7-15. https://dx.doi.org/10.2991/assehr.k.210 514.002

Hidayatulloh, F. S. (2013). Sedekah Bumi Dusun Cisampih Cilacap. El-Harakah, 15(1), $1-17$. https://dx.doi.org/10.18860/el.v15i1.26 69

Huda, M. T. (2017). Harmoni sosial dalam Tradisi Sedekah Bumi Masyarakat Desa Pancur Bojonegoro. 7(2), 267-296. https://doi.org/10.15642/religio.v7i2.75 3

Jalil, A. (2019). Resistensi Tradisi Terhadap Modernitas. Umbara, 2(2), 113-126. https://doi.org/10.24198/umbara.v2i2.2 0451

Jenks, C. (1993). Culture (Konsep Budaya) Oleh: CHRIS JENKS Penerjemah: Arie Setyaningrum Pamungkas Editor: Novi Kurnia BUDAYA. https://kalamkopi.files.wordpress.com/ 2017/04/chris-jenks-culture-konsepbudaya.pdf

Lestari, E. D, A. S. N. F. (2018). Tradisi Sedekah Bumi dalam Pelestarian Budaya Lokal di Dusun Wonosari Desa Tebang Kacang. 1-10. https://jurnal.untan.ac.id/index.php/jpd $\mathrm{pb} /$ article/view/28150

Mangunjaya, F. M., Bahagia, W. R., \& Yono. (2020). Nujuh Bulanan Tradition Value for Societies Resilience in Costumary Community Urug Bogor West Java. Sosial Budaya, 17(2), 106-117. http://dx.doi.org/10.24014/sb.v17i2.10 960 
Moleong, D. L. J. (2019). Metodologi Penelitian Kualitatif (38th ed.). Remaja Rosdakarya

Nugroho, H. (2018). Dimensi Teologi Dalam Ritual Sedekah Bumi Masyarakat Made. Jurnal Keislaman Dan Humaniora, 4(1), 24-48. https://doi.org/10.35719/islamikainside .$v 4 \mathrm{i} 1.45$

Nurrofika, N., \& Murdiono, M. (2020). Tradisi HANTA UA PUA sebagai Upaya Pelestarian Budaya Religi Di BIMA. Jurnal Antropologi: Isu-Isu Sosial Budaya, 22(1), 10. https://doi.org/10.25077/jantro.v22.n1. p10-18.2020

Pakuna, H. B., Hunowu, M. A., \& Obie, M. (2020). Traditional Wisdom of Peasant Community and Its Integration on Islamic Order in Molamahu Village of Gorontalo Regency - Indonesia. 0958(2), 81-86. https://doi.org/10.36349/EASJHCS.202 0.V02I02.012

Prasasti, S. (2020). Konseling Indigenous: Menggali Nilai-Nilai Kearifan Lokal Tradisi Sedekah Bumi dalam Budaya Jawa. Journal of Chemical Information and Modeling, 14(02), 110-123. https://doi.org/10.30957/Cendekia.v14i 2.626.satu

Riezal, C., Joebagio, H., \& Susanto, S. (2019). Kontruksi Makna Tradisi Peusijuek Dalam Budaya Aceh. Jurnal Antropologi: Isu-Isu Sosial Budaya, 20(2), 145. https://doi.org/10.25077/jantro.v20.n2. p145-155.2018

Roszi, J. P., \& Mutia. (2018). Akulturasi Nilai-Nilai Budaya Lokal dan Keagamaan dan. Jurnal Kajian Keislaman Dan Kemasyarakatan, 3(2), 172-198.

https://www.google.com/url?sa=t\&rct= $\mathrm{j} \& \mathrm{q}=\&$ esrc $=\mathrm{s} \&$ source $=$ web $\& \mathrm{~cd}=\& \mathrm{ved}$
$=2$ ahUKEwiBury8

4fzAhXEXisKHZ91AhUQFnoECAIQ

AQ\&url=http\%3A\%2F\%2Fjournal.iain curup.ac.id $\% 2$ Findex.php $\% 2$ FJF\%2Far ticle $\% 2$ Fdownload $\% 2$ F667\%2Fpdf\&us $\mathrm{g}=\mathrm{AOvVaw}$ 3LJ7Ep71jyHjNRJqLgnW $\mathrm{qE}$

Supriatna, A.L., Nugraha, Y. . (2020). Menguak Real itas Praktik Sedekah Bumi Di Desa Ciasmara Kecamatan Pamijahan Kabupaten Bogor. Jurnal Penelitian Sosial, 2, 43-60. https://doi.org/10.33751/jpsik.v4i1.180 4

Utami, L. S. S. (2015). The Theories of Intercultural Adaptation. Jurnal Komunikasi, $\quad 7(2), \quad$ 180-197. https://media.neliti.com/media/publicat ions/108215-ID-teori-teori-adaptasiantar-budaya.pdf 